Review

\title{
Lipidation of Antimicrobial Peptides as a Design Strategy for Future Alternatives to Antibiotics
}

\author{
Taylor Rounds and Suzana K. Straus *(D) \\ Department of Chemistry, University of British Columbia, 2036 Main Mall, Vancouver, BC V6T 1Z1, Canada; \\ trounds@uoguelph.ca \\ * Correspondence: sstraus@chem.ubc.ca; Tel.: +1-(604)-822-2537
}

Received: 17 November 2020; Accepted: 14 December 2020; Published: 18 December 2020

\begin{abstract}
Multi-drug-resistant bacteria are becoming more prevalent, and treating these bacteria is becoming a global concern. One alternative approach to combat bacterial resistance is to use antimicrobial (AMPs) or host-defense peptides (HDPs) because they possess broad-spectrum activity, function in a variety of ways, and lead to minimal resistance. However, the therapeutic efficacy of HDPs is limited by a number of factors, including systemic toxicity, rapid degradation, and low bioavailability. One approach to circumvent these issues is to use lipidation, i.e., the attachment of one or more fatty acid chains to the amine groups of the N-terminus or a lysine residue of an HDP. In this review, we examined lipidated analogs of 66 different HDPs reported in the literature to determine: (i) whether there is a link between acyl chain length and antibacterial activity; (ii) whether the charge and (iii) the hydrophobicity of the HDP play a role; and (iv) whether acyl chain length and toxicity are related. Overall, the analysis suggests that lipidated HDPs with improved activity over the nonlipidated counterpart had acyl chain lengths of 8-12 carbons. Moreover, active lipidated peptides attached to short HDPs tended to have longer acyl chain lengths. Neither the charge of the parent HDP nor the percent hydrophobicity of the peptide had an apparent significant impact on the antibacterial activity. Finally, the relationship between acyl chain length and toxicity was difficult to determine due to the fact that toxicity is quantified in different ways. The impact of these trends, as well as combined strategies such as the incorporation of $\mathrm{D}$ - and non-natural amino acids or alternative approaches, will be discussed in light of how lipidation may play a role in the future development of antimicrobial peptide-based alternatives to current therapeutics.
\end{abstract}

Keywords: antimicrobial peptide (AMP); host-defense peptide (HDP); lipidation

\section{Introduction}

Due to the overuse or misuse of antibiotics, multi-drug-resistant bacteria are becoming more prevalent [1-3]. The ESKAPE pathogens (Enterococcus faecium, Staphylococcus aureus, Klebsiella pneumoniae, Acinetobacter baumannii, Pseudomonas aeruginosa, and Enterobacter spp.) are the leading cause of hospital-acquired infections [4], and thus their growing resistance to antibiotics is a global concern $[4,5]$. One alternative approach that is being explored is the use of antimicrobial peptides (AMPs) [6-10], which are also known as host-defense peptides (HDPs). These are small active peptides that are found in all life forms, including bacteria and plants [7]. AMPs are beneficial to bacteria because they are capable of killing other species of bacteria that may compete for nutrients. Likewise, HDPs play a key role in protecting plants against bacterial infection. Thus, AMPs have received significant attention because of their antimicrobial activity against a broad spectrum of pathogens, including both Gram-positive and Gram-negative bacteria [11-14]. In addition, HDPs attack bacteria using a mechanism that is different from that used by most conventional antibiotics, and as a result, little evidence of resistance has been seen against these peptides $[6,7,13,15]$. Conventional antibiotics typically act on a specific cellular 
target as a way of initiating cellular death [16]. However, many HDPs use nonmediated membrane destruction in which disruption of the cell membrane leads to cell lysis and ultimately death. As a result, it is more difficult for bacteria to develop resistance to HDPs. In addition to this, evidence has also shown that HDPs can enter a bacterial cell in order to interact with intracellular targets by binding to DNA and RNA or promoting the production of reactive oxygen species to cause further damage [8,16]. Finally, HDPs can additionally modulate the immune response [17-19] or display anticancer activity [20-22]. This diversity in their mode of action has sparked great interest in the clinical potential of these HDP-based therapies.

Despite their potential, HDPs have limitations due to a number of factors. Firstly, natural HDPs mostly consist of L-amino acids, making them susceptible to protease degradation and rapid kidney clearance [23-25]. Moreover, some AMPs display systemic toxicity by not being specific to bacteria. Indeed, systemic administration results in cytotoxic profiles in blood and short half-lives in vivo [17]. Many approaches have been investigated to circumvent these limitations $[7,8]$. These include the use of delivery vehicles [26] and chemical modification of AMPs [27]. Approaches to increase activity, specificity, biocompatibility, and stability include the inclusion of unnatural amino acids [27-29], peptide cyclization [30-32], the incorporation of D-amino acids [7,33,34], as well as the conjugation of carbohydrates [35] or fatty acids [36-38].

Lipidation, i.e., the attachment of one or more fatty acid chains to $\mathrm{N}$-terminal residues or lysine side-chains of an HDP, has been of particular interest. It has been shown in previous studies that lipidation of AMPs can improve the antimicrobial potency of the peptides without altering their properties [36,39]. It has been suggested that this improved potency is due to enhanced interactions between the bacterial cell membrane and the fatty acid-peptide conjugate [38]. However, although conjugation of fatty acids to the peptide can cause improvements to antimicrobial activity, this is not always the case as the antimicrobial activity is highly dependent on the length of the acyl chain. As acyl chains increase in length, there is an increased tendency for self-assembly to occur. As a result of the altered water-membrane partition equilibrium, the hydrophobic chains conjugated to the peptides would have reduced interaction with water, and thus this reduces the chance of peptide-membrane interaction. In addition, as the length of the conjugated fatty acids increases, toxicity towards mammalian cells increases due to poor membrane selectivity $[35,38]$. Overall, although the acylation of AMPs has been proven to provide benefits to the antimicrobial activity, there appear to be optimal lengths of fatty acid chains in which the antimicrobial activity is increased, but the toxicity towards mammalian cells is not a concern. This literature review will provide an overview of the previous studies in which various lengths of fatty acid chains have been conjugated to AMPs, and the effects on antibacterial activity and toxicity will be discussed. The trends that are seen based on the hydrophobicity of the original peptide, the number of amino acids in the peptide, and the charge of the peptide will be studied to determine if any direction to future studies can be given. Basic design rules may provide important guidelines for the design of future lipidated HDP-based alternatives to antibiotics.

\section{Review of the Lipidation Literature}

Sixty-six different HDPs, which had been lipidated or modified in other ways (e.g., conjugation with benzoic acid [38], cinnamic acid [40], and so on), were found in papers dated from 1978 to 2020, with most references dating from 2002 onwards. Lists of minimum inhibitory concentrations (MIC) against a number of bacteria (E. coli, P. aeruginosa, A. baumannii, and S. aureus), minimum biofilm eradication concentrations (MBEC) against S. aureus, and toxicity were generated for these 66 HDPs. Peptides for which data with a range of acyl chain lengths were available were considered further (Table 1). Excluded HDPs include studies where the peptide sequence was varied, but not the length of the acyl chain [41], or studies where only the HDP + 1 acyl-modified HDP were reported [42]. For the remaining $47 \mathrm{HDPs}$, their length, charge (for the peptide alone), and percent hydrophobic content were tabulated and are given in Table 1. 
Table 1. List of host-defense peptides (HDPs) and some of their properties used to generate the plots in Figure 1.

\begin{tabular}{|c|c|c|c|c|c|}
\hline Peptide & Sequence & \# Amino Acids & Charge $^{1}$ & $\%$ Hydrophobic ${ }^{2}$ & Reference \\
\hline 1 & KRIVQRIKDFLR & 12 & +5 & 42 & [38] \\
\hline 2 & FQWQRNIRKVR & 11 & +5 & 36 & [43] \\
\hline 3 & oOWW ${ }^{3}$ & 4 & +3 & 50 & {$[40,44,45]$} \\
\hline 4 & RWRWRW & 6 & +4 & 50 & [46] \\
\hline 5 & LWKTLLKKVLKAAA & 14 & +5 & 64 & [47] \\
\hline 6 & WKTLLKKVLKAAA & 13 & +5 & 62 & [47] \\
\hline 7 & KTLLKKVLKAAA & 12 & +5 & 58 & [47] \\
\hline 8 & TLLKKVLKAAA & 11 & +4 & 64 & [47] \\
\hline 9 & ALWKTLLKKVLKA & 13 & +5 & 62 & [48] \\
\hline 10 & KYR & 3 & +3 & 0 & [49] \\
\hline 11 & SKVWRHWRRFWHRAHRKL & 18 & +8 & 39 & [50] \\
\hline 12 & YGAAKKAAKAAKKAAKAA & 18 & +7 & 56 & {$[42,51]$} \\
\hline 13 & KLLK & 4 & +3 & 50 & [52] \\
\hline 14 & KAAK & 4 & +3 & 50 & [52] \\
\hline 15 & KKK & 3 & +4 & 0 & [53] \\
\hline 16 & RRWQWRMKK & 9 & +6 & 33 & [54] \\
\hline 17 & LKKLLKKLLKKL & 12 & +7 & 50 & [39] \\
\hline 18 & KKKK & 4 & +5 & 0 & [55] \\
\hline 19 & DapKKK 4 & 4 & +5 & 0 & [56] \\
\hline 20 & DabKKK $^{5}$ & 4 & +5 & 0 & {$[56]$} \\
\hline 21 & KKLLKLLLKLLK & 12 & +6 & 58 & [57] \\
\hline 22 & GIGKFLHSAKKWGKAFVGEIMNS & 23 & +4 & 43 & [57] \\
\hline 23 & RRRR & 4 & +5 & 0 & [58] \\
\hline 24 & VDabGSWSDabDabFEVIA & 13 & +3 & 46 & {$[59,60]$} \\
\hline 25 & RGRKVVRRKK & 10 & +8 & 20 & {$[61]$} \\
\hline 26 & RGRKGGRRKK & 10 & +8 & 0 & [61] \\
\hline 27 & GATAIKQVKKLFKKKGG & 17 & +7 & 35 & [62] \\
\hline 28 & RWKRHISEQLRRRDRLQRQAJ & 21 & +7 & 25 & [63] \\
\hline 29 & IKQVKKLFKK & 10 & +6 & 40 & [64] \\
\hline 30 & LLWIALRKK & 9 & +4 & 67 & [65] \\
\hline 31 & KKLLKLLLKLLK & 12 & +6 & 58 & [66] \\
\hline 32 & KKLLKKLKKLLK & 12 & +8 & 42 & [66] \\
\hline 33 & KKKLKKLKKKLK & 12 & +10 & 25 & [66] \\
\hline 34 & GLLKRIKTLL & 10 & +4 & 50 & {$[16,67]$} \\
\hline 35 & RKWWK & 5 & +4 & 40 & {$[68]$} \\
\hline 36 & RFWR & 4 & +3 & 50 & [69] \\
\hline 37 & RR & 2 & +3 & 0 & [70] \\
\hline 38 & KKC & 3 & +3 & 0 & [71] \\
\hline 39 & KR & 2 & +3 & 0 & [71] \\
\hline 40 & $\mathrm{O}$ & 1 & +2 & 0 & [72] \\
\hline 41 & $\mathrm{OO}$ & 2 & +3 & 0 & [72] \\
\hline 42 & $\mathrm{OOO}$ & 3 & +4 & 0 & [72] \\
\hline 43 & OOOO & 4 & +5 & 0 & [72] \\
\hline 44 & OOOOO & 5 & +6 & 0 & [72] \\
\hline 45 & RIRIRWIIR & 9 & +5 & 56 & [35] \\
\hline 46 & KRRVRWIIW & 9 & +5 & 56 & [35] \\
\hline \multirow[t]{2}{*}{47} & YVLWKRKRKFCFI & 13 & +6 & 46 & [73] \\
\hline & AVERAGE \pm St. Deviation & $9 \pm 5$ & $5 \pm 2$ & $32 \pm 24$ & \\
\hline
\end{tabular}

${ }^{1}$ Charge for nonlipidated HDPs. Most HDPs have an amidated C-terminus. ${ }^{2}$ Using https://www.peptide2.com/N_peptide_ hydrophobicity_hydrophilicity.php for peptides with natural amino acids. ${ }^{3} \mathrm{O}=$ Orn. ${ }^{4}$ Dap $=2,3$-diamino-propionic acid. ${ }^{5} \mathrm{Dab}=2,4$-diaminobutyric acid.

\subsection{Length of Acyl Chain}

For each of the 47 different HDPs in Table 1, the number of lipidated HDPs that represented the most active antibacterial (i.e., lowest MIC) for a given acyl chain length were tallied and counted. Figure 1a shows that the optimal chain lengths are most commonly found to be $\mathrm{C} 8-\mathrm{C} 12$. Interestingly, this trend is consistent for E. coli, P. aeruginosa, and S. aureus. It should be noted that the trend is less clear for A. baumanii, most likely due to the fact that there were only 13 HDPs for which data were available, as compared to the $>40$ peptides for each of the other bacteria. The aim was to also see if this 
trend is mirrored in terms of MBEC values, but there were only five values available in our list, so we did not analyze MBEC data further.

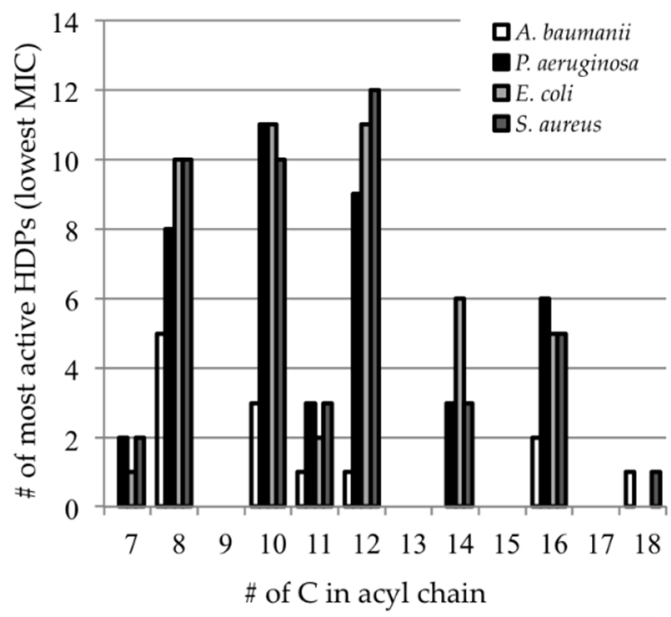

(a)

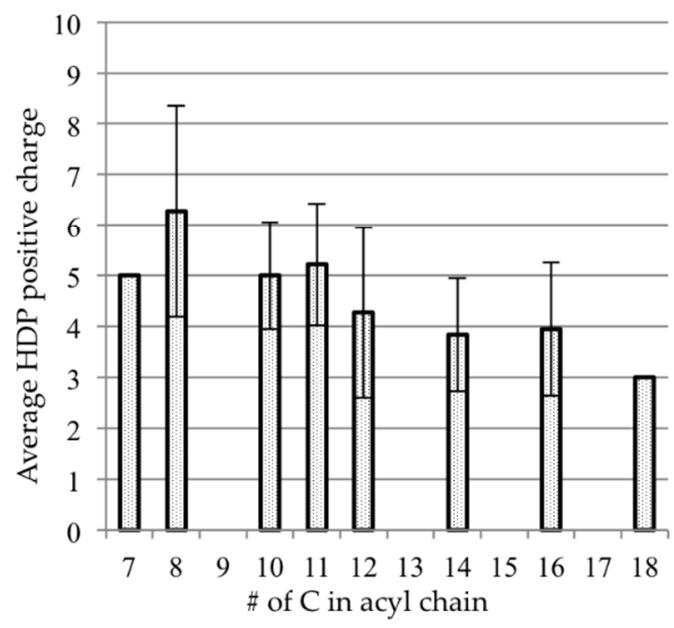

(c)

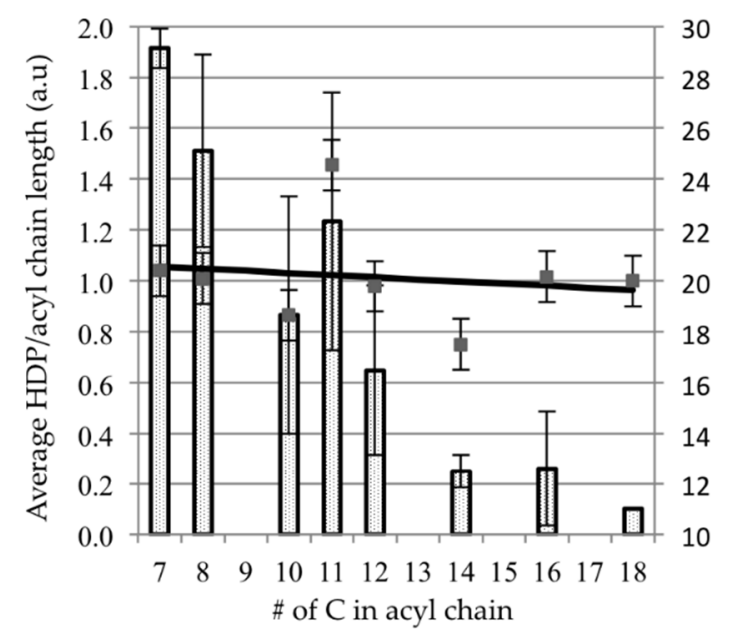

(b)

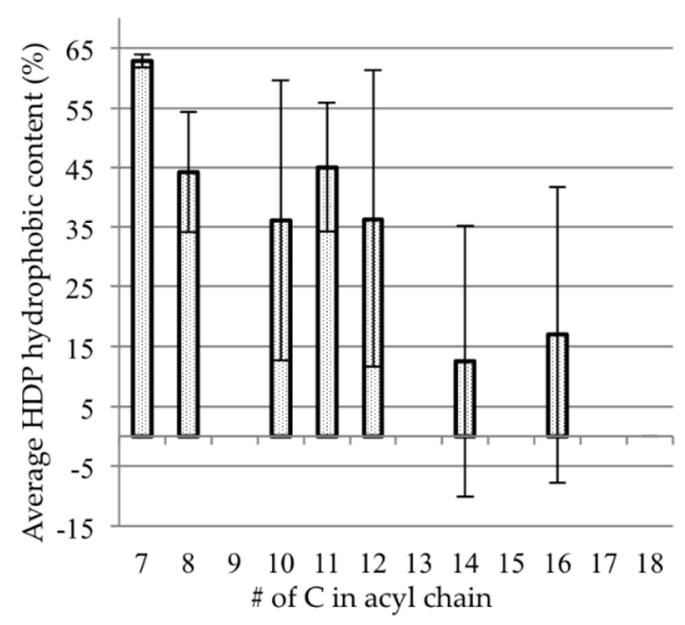

(d)

Figure 1. Comparison of lipidated HDPs listed in Table 1 as a function of acyl chain length. (a) Number of lipidated HDPs for which a given acyl chain length results in the lowest MIC for 4 different bacteria; (b) average ratio of HDP length and acyl chain length (number of amino acids/number of Cs in the acyl chain)-bars; and total length (squares and fitted line); (c) average charge of the parent (nonlipidated) HDP; (d) average percent hydrophobic content for the parent HDP. In panel (b), a comparison of C8 versus $\mathrm{C} 12$ and $\mathrm{C} 8$ versus $\mathrm{C} 16$ yields $p$-values $<0.001$. For panels $(\mathbf{c}, \mathbf{d})$, a similar comparison yields $\mathrm{p}$-values that indicate that the differences are not significant.

The trend shown in Figure 1a is possibly linked to these acyl chain lengths being most conducive to secondary structure formation and membrane insertion. Indeed, Mak et al. showed that acylated peptides, specifically with acyl chains of 8,10 , or 12 carbons, were observed to have higher $\alpha$-helical content in comparison to the parent peptide in the presence of large unilamellar liposomes or trifluoroethanol, a membrane mimic [74]. Moreover, these same lipidated helical peptides inserted into the liposomes most effectively, demonstrating that the $\alpha$-helical structure of a lipopeptide is clearly correlated to the ability to disrupt a bacterial membrane. Furthermore, conjugates with longer acyl chains may lead to a decrease in the activity due to aggregation and self-assembly [38,48,50,58]. Indeed, Sikorska et al. showed that the monomeric forms of short arginine-rich HDPs were responsible for the disruption of the bacterial membrane as opposed to aggregated forms [58]. In order to examine 
whether the length of the HDP plays a role in this trend, the data were re-examined in terms of the relative ratio of HDP length and acyl chain length.

\subsection{Relative HDP and Acyl Chain Lengths}

In Figure $1 b$, the average ratio of HDP length to acyl chain length is presented as a function of the acyl chain length. This takes into account all data for the four bacterial strains listed in Section 2.1. What can be observed is that for short chain lengths, the HDPs tend to be longer than for longer acyl chain lengths (bars, Figure 1b). Interestingly, the total length of HDP and acyl chain is fairly constant at 20 (number of amino acids + acyl Cs, squares and fitted line, Figure 1b). This translates to a molecule that would have a total length of 31-33 $\AA$, assuming the HDP is $\alpha$-helical, which most HDPs in Table 1 are. This number matches more closely the POPC/POPG bilayer thickness of $\sim 39 \AA$ than the individual peptide, suggesting that the lipidated peptide might insert more readily. POPC/POPG bilayers have been shown to be reasonable models to mimic bacterial membranes [75].

\subsection{Charge of HDPs}

Next, the effect of the charge of the HDP was examined to see if any trends were to be observed. Figure 1c shows the average charge of the HDPs as a function of acyl chain length, again using the data for all the bacterial strains discussed in Section 2.1. Here, there are no clear trends to be seen. This suggests that the burial of the acyl chain may be the driving force for the insertion of lipidated peptides, making cationicity less important.

\subsection{Hydrophobic Content of HDPs}

Finally, the effect of the hydrophobic content of the HDP was examined. Figure $1 \mathrm{~d}$ shows the average hydrophobicity of the HDPs as a function of acyl chain length (using data from Section 2.1). As with charge, there are no clear trends to be seen, which could again imply that the hydrophobicity of the acyl chain is the important factor leading to the efficient insertion of lipidated peptides into the bacterial membrane.

\subsection{Caveats}

It should be noted that the number of data points for certain parameters is limited; e.g., A. baumannii, C18 HDPs. Consequently, the trends described above should be used as rough rules of thumb in designing lipidated HDPs. More detailed molecular descriptors [76-78] provide more stringent design rules.

\subsection{Toxicity}

An attempt to examine how toxicity depends on acyl chain length was also made. As observed by Kamysz et al. [38], such comparisons are, however, difficult to make because of the lack of uniformity in the reported toxicity values. Some studies list HC50 values [35], i.e., concentrations where 50\% hemolysis occurs, whereas others report minimum hemolytic concentrations (MHC) [38]. Others still give the $\%$ of hemolysis relative to the MIC [39]. Furthermore, one general observation can be made on the dependence of toxicity on acyl chain length: the longer the acyl chain, the greater the hemolysis. For example, Figure 3 in [38] and in [35] clearly exemplify this. As mentioned above, this trend is likely due to poor membrane selectivity [35,38], i.e., the insertion of the lipidated peptide for long acyl chains is driven by the burial of hydrophobic groups and is insensitive to the surface composition of the membrane. 


\section{Combining Lipidation with Other Methods to Increase Biocompatibility, Stability, Activity, and Specificity}

A number of studies encountered during the literature review used a combination of approaches to improve the activity of lipidated HDPs. For example, Zhong et al. [16] found that exchanging two lysine L-amino acids for the D-enantiomers in anoplin significantly decreased the antibacterial activity of the peptide. However, the conjugation of acyl chains to the peptide containing D-enantiomers improved the antibacterial activity better than the parent peptide, and in addition, resulted in better stability against proteases. Another study conducted by Lee et al. on peptide CopW demonstrated that exchanging all $\mathrm{L}$-amino acids for $\mathrm{D}$-amino acids increased the antibacterial activity against some bacterial strains [65]. The antibacterial activity was further improved when acyl chains were conjugated to the $\mathrm{N}$-terminus. The peptide composed of D-amino acids was also shown to have significantly better stability in serum. There has been much evidence to suggest that stability can be provided through the incorporation of D-amino acids into HDPs [66,79-81]. The addition of lipidation serves to further improve activity, making the resulting compounds of interest.

Although examples of lipidated HDPs with non-natural amino acids have been reported (Table 1) $[59,82]$, to the best of our knowledge, there are no studies that systematically examine the effect of changing L-amino acids for non-natural ones on the activity of lipidated HDPs of varying acyl chain length. Since a number of studies have shown that incorporating unnatural amino acids can improve stability $[27,28,80]$, it is expected that this combined approach could yield valuable antimicrobials. Indeed, a number of studies on lipidated peptoids have been reported $[83,84]$ and show that the combined use of acyl chains and non-natural peptides are highly active.

\section{Comparison of Lipidation to Other Methods to Increase Biocompatibility, Stability, Activity and Specificity}

In order to assess how valid lipidation is as a design strategy for future alternatives to antibiotics, it is important to understand its advantages and disadvantages in the context of other currently available methods (Figure 2), i.e., chemical modification of HDPs such as the inclusion of D-amino acids, the rational substitution of amino acids, cyclization/stapling, and peptidomimetics.

The substitution of L-amino acids for D-amino acids (Figure 2) is an approach typically used to prevent the degradation of HDPs by proteases [7]. Generally, changing the stereochemistry of an amino acid often does not significantly affect the antimicrobial activity of the peptide. For example, the MICs of the D-amino acid counterpart of peptide 73 were very similar to its fully L-amino acid version [79]. In other words, this approach is not usually used as a way to improve activity but rather simply to improve stability. For instance, Jia et al. replaced all L-amino acids for D-amino acids in the HDP polybia-CP, thereby making it resistant to trypsin and chymotrypsin degradation, without compromising its activity against both Gram-negative and Gram-positive bacteria [33]. Moreover, these authors noted that the single substitution of the L-lysine for D-lysine helped to improve stability and substantially decreased its hemolytic activity while only slightly decreasing antimicrobial activity [34]. Furthermore, studies have shown that introducing D-amino acids can lower host toxicity [79,85-87]. Finally, compared to lipidation, D-peptide synthesis is more costly [88], thereby often hindering its application in the clinic.

The rational substitution of amino acids to generate new HDPs has been explored extensively over the years $[6,7,89,90]$. For example, a recent review [91] has illustrated how peptides can be engineered from HDPs found in nature, e.g., temporins and aureins. This approach is typically used to improve antimicrobial activity and reduce hemolytic activity $[88,92,93]$. Sequences are varied by changing the position of positively charged amino acids (e.g., Lys) within the hydrophilic and hydrophobic segments of the HDP $[88,92]$. For example, antimicrobial activity against both Gram-positive and Gram-negative bacteria has been shown to improve by the substitution of lysine in the hydrophilic face of magainin II. This has been complemented with slight reductions in hemolytic activity. Conversely, activity is affected in various ways when Lys substitution occurs in the hydrophobic face of magainin, 
the extent of which depends on the residue being replaced [88]. Interestingly, the positioning of Lys in the hydrophobic face of the HDP is accompanied by a decrease in hemolysis. Alternatively, more active peptides are designed by adding arginine and/or tryptophan residues [89,94,95]. Cationic residues (i.e., Lys and Arg) help facilitate the initial electrostatic interaction between HDPs and the bacterial cytoplasmic membrane $[90,95]$, whereas Trp residues facilitate peptide-lipid interactions (Figure 2) by preferably binding to the interfacial region of membranes [90]. In addition, the use of both Trp and Arg amino acids allows for cation- $\pi$ interactions, which can further contribute to favorable peptide-membrane interactions $[89,95]$. Overall, the process of rational substitution serves to directly reduce MICs and hopefully also improve selectivity, as most approaches optimize activity first and foremost. Compared to the lipidation approach, the substitution of amino acids typically involves the generation of large libraries of peptides (e.g., $>5-10$ [91] to multiple hundreds of peptides $[76,96]$ ). In contrast, most of the lipidation studies reviewed in Section 2 involved the synthesis of $<10$ analogs. However, lipidation generally results in less selective compounds, as discussed in Section 2.5.

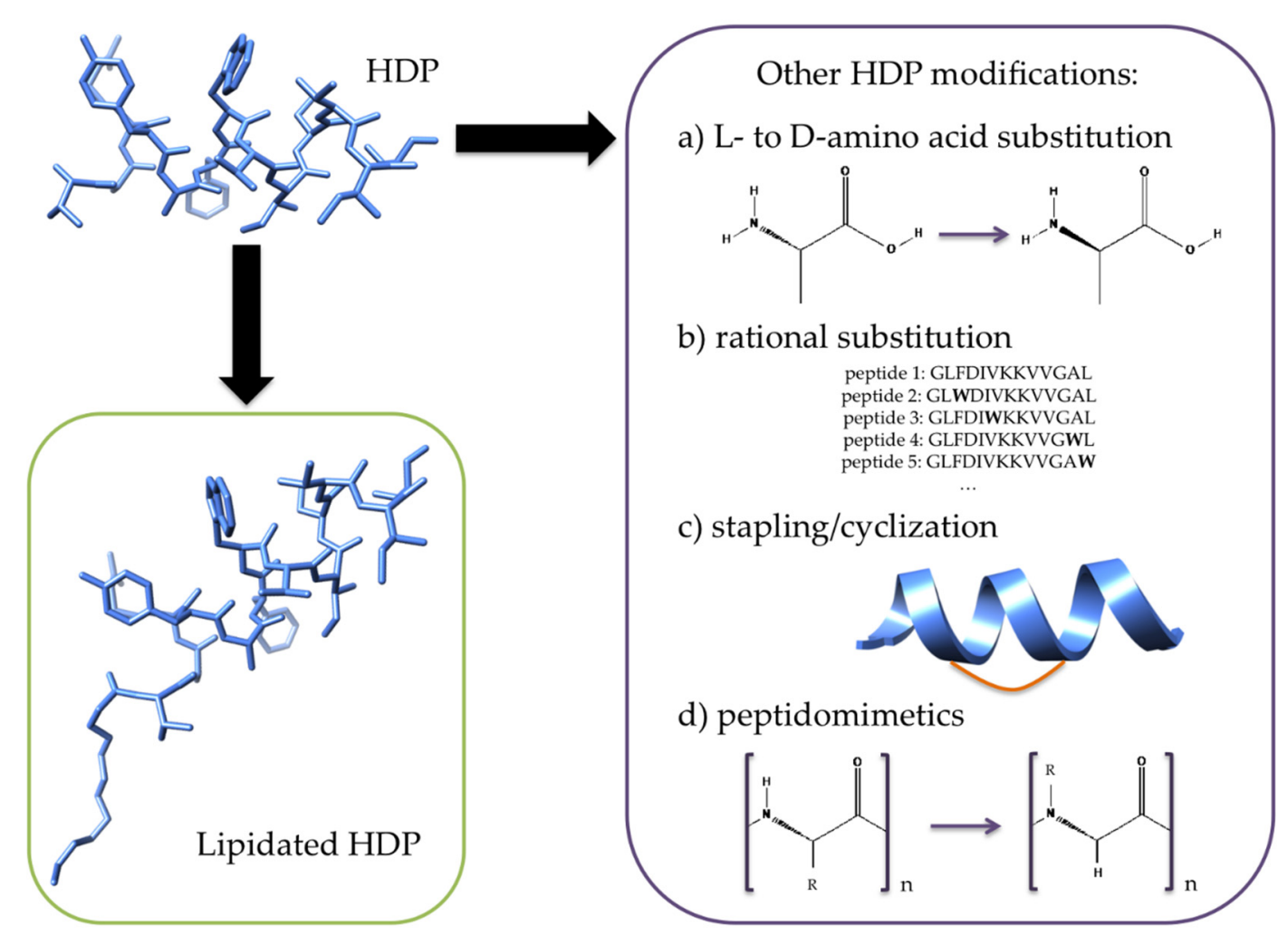

Figure 2. Comparison of lipidated HDPs (green box) to alternative approaches (purple box): replacement of one or more L-amino acids for D-amino acids in the HDP, rational substitution of amino acids, stapling or cyclization, and, finally, the use of peptidomimetics, where, e.g., the side chain (designated as R) is not on the $\mathrm{C} \alpha$ but rather on the $\mathrm{N}$ atom.

Cyclization is another common method to protect peptides against protease degradation. A number of approaches exist to accomplish this, such as head-to-tail cyclization, side-chain-to-tail cyclization, and using disulfide bridges via cysteine residues [97]. Alternatively, one or more staples (i.e., using $\alpha$-methylated amino acids [98]) can be incorporated between $i, i+4$ or $i+7$ residues (Figure 2), thereby locking the peptide into an $\alpha$-helical structure with twisted amide bonds, which makes them less favorable to proteolytic cleavage [30,88]. Alternatives to all hydrocarbon-based approaches include nitrogen and sulfur arylation of lysine and cysteine residues, respectively [31,32]. Though cyclization does indeed increase resistance to proteolysis, it often comes with unpredictable and undesired effects on mammalian membrane lysis, antimicrobial activity, and peptide solubility $[30,88]$. Recently, a systematic study by Mourtada et al. examined the structure-function-toxicity relationship 
of 58 stapled AMP (StAMP) constructs of magainin II in order to devise an algorithm to predict stable, nontoxic StAMPs [88]. The authors sequentially incorporated $i, i+4$ staples at different positions in the magainin II sequence so as to determine which staple placement had minimal undesired effects on hemolytic activity. Interestingly, they found that when staples were placed within an already established hydrophobic face, the resulting StAMPs were less hemolytic. On the other hand, placement of stapled in a region of low hydrophobicity had an impact on the activity. Using their algorithm, Mourtada et al. were finally able to generate de novo StAMPs that showed strong antimicrobial activity and little to no hemolysis. This was done without having to resort to a costly synthetic library. Recent work by Etayash et al. [97] has shown that cyclization of the HDP IDR-1018 only slightly improved the MIC relative to the parent peptide. The main advantage in the cyclization of IDR-1018 was seen in the results obtained from a murine cutaneous abscess model, where the stability of the cyclic peptide was directly correlated to improved wound healing. Overall, the cyclization of peptides involves a number of complex steps, which can result in low yields [98]. Lipidation, on the other hand, appears to be more straightforward, as long as strategies such as a second coupling [35] are used.

Finally, peptidomimetic approaches involve using modified amino acids or amino-acid-like units (Figure 2) to generate mimics that imitate the structure, activity, and mode of action of HDPs. A key design feature is that the overall amphiphilic structure of the original peptide is maintained $[7,99,100]$. As a result of their non-natural composition, peptidomimetics are able to improve in vivo half-life and stability relative to HDPs. In many cases, the use of mimics also helps improve toxicity and lower synthesis costs [9,99-101]. Indeed, many successful HDPs in clinical trials are nonpeptidic derivatives, such as, e.g., the defensin mimetic brilacidin $[9,102]$. Other examples include the recent work by Luther et al., who recently developed a class of peptidomimetics built using a mixture of synthetic building blocks and natural amino acids arranged into two linked macrocycles [103]. A number of these derived compounds exhibited strong efficacy in a variety of mouse models of infection, activity against a wide array of bacteria (including in serum), favorable tolerability and pharmacokinetics, and low cell toxicity. A number of reviews can be consulted for further examples $[9,99,100]$. The complexity and cost of synthesis appear to be on par with lipidation approaches.

Overall, one of the main advantages of lipidation over the alternative strategies presented above appears to be the marked improvement in the activity of lipidated HDPs [35,37,38], which can be easily achieved through the $\mathrm{N}$-terminus conjugation of $\mathrm{C}_{8}-\mathrm{C}_{12}$ fatty acid chains, using a small number of constructs. Moreover, the cost and ease of synthesis appear to be generally lower than some of the other methods. Although many of the studies surveyed here do not examine stability, some examples can be found in the literature. For instance, Lombardi et al. used the fact that lipidated HDPs tend to self-assemble to generate nanostructures that showed improved antibiofilm activity and protease stability [37]. These compounds were made by linking the HDPs to an aliphatic polyalanine peptide, which in turn was attached to a $\mathrm{C}_{19}$ lipidic tail. In terms of disadvantages, the main problem with lipidation is the increased cytotoxicity of the peptides, which increases with larger carbon length $[35,38,104]$.

\section{Discussion}

The increase in levels of bacterial antibiotic resistance has led researchers to look for alternatives to current antibiotics $[3,105]$. HDPs or synthetic analogs are considered to be interesting substitutes because they can function in a variety of ways $[6,7,106]$. Recently, a number of studies have shown that lipidation results in HDPs with improved activity. As long as the chain length is well chosen, a balance exists between improved antibacterial properties and selectivity. Interestingly, many of the active lipidated peptides have acyl chain lengths of $\mathrm{C}_{8}-\mathrm{C}_{12}$ (Figure 1a) and short HDPs have longer acyl chains so that the overall length of the system matches closely the bacterial membrane bilayer thickness. The net charge of the HDP and its hydrophobic content play no significant role in determining activity. Most of the lipidated peptides surveyed here had the acyl chain conjugated at the $\mathrm{N}$-terminus. However, there were a few studies in which the acyl chains were conjugated at 
locations that were not the $\mathrm{N}$-terminus and these were successful as well. For example, the study by Albada et al. [46] attached acyl chains to lysine side-chains. Similarly, other examples have been reported in which acyl chains have been attached to the lysine side-chain and where improvements in antibacterial activity have been observed $[35,55,67]$. Another unique approach is shown in the study by Stachurski et al. [56], in which 2,4-diaminobutyric and 2,3-diaminopropionic acids are used as linkers at the $\mathrm{N}$-terminus to which the acyl chains were attached.

Overall, designing future lipidated HDPs is a useful strategy for developing viable alternatives to antibiotics. A comparison with alternative methods to improve biocompatibility, stability, activity, and specificity demonstrated that lipidation offers many advantages. Although toxicity is still an important impediment to the wide use of lipidated HDPs, future designs may find a way to circumvent this issue. Furthermore, each new design will provide a better fundamental understanding of the important features required for activity and minimal toxicity. Finally, a combination of approaches, i.e., using D-amino acids or unnatural amino acids, cyclization, and so on, will ensure that lipidated HDPs become viable future alternatives to antibiotics.

Author Contributions: T.R. wrote the original draft. T.R. and S.K.S. contributed to the final version. Both authors have read and agreed to the published version of the manuscript.

Funding: S.K.S. acknowledges funding from the Natural Sciences and Engineering Research Council of Canada (NSERC). T.R. acknowledges funding in the form of a NSERC undergraduate summer research award.

Acknowledgments: We thank Walter R.P. Scott for critically reading through this manuscript.

Conflicts of Interest: The authors declare no conflict of interest.

\section{Abbreviations}

$\begin{array}{ll}\text { AMP } & \text { Antimicrobial peptide } \\ \text { HDP } & \text { Host-defense peptide } \\ \text { MIC } & \text { Minimum inhibitory concentration } \\ \text { MBEC } & \text { Minimum biofilm eradication concentration } \\ \text { Orn } & \text { Ornithine } \\ \text { POPC } & \text { 1-palmitoyl-2-oleoyl-sn-glycero-3-phosphocholine } \\ \text { POPG } & \text { 1-Palmitoyl-2-oleoyl-sn-glycero-3-phosphoglycerol }\end{array}$

\section{References}

1. Andrei, S.; Valeanu, L.; Chirvasuta, R.; Stefan, M.-G. New FDA approved antibacterial drugs: $2015-2017$. Discoveries 2018, 6, e81. [CrossRef]

2. Theuretzbacher, U.; Piddock, L.J.V. Non-traditional Antibacterial Therapeutic Options and Challenges. Cell Host Microbe 2019, 26, 61-72. [CrossRef] [PubMed]

3. Chellat, M.F.; Raguž, L.; Riedl, R. Targeting Antibiotic Resistance. Angew. Chem. Int. Ed. 2016, 55, 6600-6626. [CrossRef]

4. Santajit, S.; Indrawattana, N. Mechanisms of Antimicrobial Resistance in ESKAPE Pathogens. BioMed Res. Int. 2016, 2016, 2475067. [CrossRef]

5. Yewale, V.N. Antimicrobial resistance-A ticking bomb! Indian Pediatr. 2014, 51, 171-172. [CrossRef]

6. Haney, E.F.; Straus, S.K.; Hancock, R.E.W. Reassessing the Host Defense Peptide Landscape. Front. Chem. 2019, 7, 43. [CrossRef] [PubMed]

7. Kumar, P.; Kizhakkedathu, J.N.; Straus, S.K. Antimicrobial Peptides: Diversity, Mechanism of Action and Strategies to Improve the Activity and Biocompatibility In Vivo. Biomolecules 2018, 8, 4. [CrossRef]

8. Drayton, M.; Kizhakkedathu, J.N.; Straus, S.K. Towards Robust Delivery of Antimicrobial Peptides to Combat Bacterial Resistance. Molecules 2020, 25, 3048. [CrossRef]

9. Kuppusamy, R.; Willcox, M.D.; Black, D.S.; Kumar, N. Short Cationic Peptidomimetic Antimicrobials. Antibiotics 2019, 8, 44. [CrossRef] 
10. Pizzo, E.; Cafaro, V.; di Donato, A.; Notomista, E. Cryptic Antimicrobial Peptides: Identification Methods and Current Knowledge of their Immunomodulatory Properties. Curr. Pharm. Des. 2018, 24, 1054-1066. [CrossRef]

11. de la Fuente-Núñez, C.; Cardoso, M.H.; Cândido, E.D.S.; Franco, O.L.; Hancock, R.E. Synthetic antibiofilm peptides. Biochim. Biophys. Acta Biomembr. 2016, 1858, 1061-1069. [CrossRef]

12. Yasir, M.; Willcox, M.D.; Dutta, D. Action of Antimicrobial Peptides against Bacterial Biofilms. Materials 2018, 11, 2468. [CrossRef]

13. Raheem, N.; Straus, S.K. Mechanisms of Action for Antimicrobial Peptides with Antibacterial and Antibiofilm Functions. Front. Microbiol. 2019, 10, 2866. [CrossRef] [PubMed]

14. Magana, M.; Pushpanathan, M.; Santos, A.L.; Leanse, L.; Fernandez, M.; Ioannidis, A.; Giulianotti, M.A.; Apidianakis, Y.; Bradfute, S.; Ferguson, A.L.; et al. Faculty Opinions recommendation of the value of antimicrobial peptides in the age of resistance. Lancet Infect. Dis. 2020, 20, 216. [CrossRef]

15. Mookherjee, N.; Anderson, M.A.; Haagsman, H.P.; Davidson, D.J. Antimicrobial host defence peptides: Functions and clinical potential. Nat. Rev. Drug Discov. 2020, 19, 311-332. [CrossRef] [PubMed]

16. Zhong, C.; Zhu, N.; Zhu, Y.; Liu, T.; Gou, S.; Xie, J.; Yao, J.; Ni, J.-M. Antimicrobial peptides conjugated with fatty acids on the side chain of D-amino acid promises antimicrobial potency against multidrug-resistant bacteria. Eur. J. Pharm. Sci. 2020, 141, 105123. [CrossRef] [PubMed]

17. Haney, E.F.; Hancock, R.E. Peptide design for antimicrobial and immunomodulatory applications. Biopolymers 2013, 100, 572-583. [CrossRef]

18. Bowdish, D.M.E.; Davidson, D.J.; Scott, M.G.; Hancock, R.E.W. Immunomodulatory Activities of Small Host Defense Peptides. Antimicrob. Agents Chemother. 2005, 49, 1727-1732. [CrossRef]

19. Bowdish, D.M.E.; Davidson, D.J.; Hancock, R.E.W. A Re-evaluation of the Role of Host Defence Peptides in Mammalian Immunity. Curr. Protein Pept. Sci. 2005, 6, 35-51. [CrossRef]

20. Felício, M.R.; Silva, O.N.; Gonçalves, S.; Santos, N.C.; Franco, O.L. Peptides with Dual Antimicrobial and Anticancer Activities. Front. Chem. 2017, 5, 5. [CrossRef]

21. Hoskin, D.W.; Ramamoorthy, A. Studies on anticancer activities of antimicrobial peptides. Biochim. Biophys. Acta Biomembr. 2008, 1778, 357-375. [CrossRef] [PubMed]

22. Chernysh, S.; Kim, S.I.; Bekker, G.; Pleskach, V.A.; Filatova, N.A.; Anikin, V.B.; Platonov, V.G.; Bulet, P. Antiviral and antitumor peptides from insects. Proc. Natl. Acad. Sci. USA 2002, 99, 12628-12632. [CrossRef] [PubMed]

23. Jenssen, H.; Hamill, P.; Hancock, R.E.W. Peptide Antimicrobial Agents. Clin. Microbiol. Rev. 2006, 19, 491-511. [CrossRef] [PubMed]

24. Andersson, D.I.; Hughes, D.; Kubicek-Sutherland, J.Z. Mechanisms and consequences of bacterial resistance to antimicrobial peptides. Drug Resist. Updat. 2016, 26, 43-57. [CrossRef] [PubMed]

25. Vaara, M. New approaches in peptide antibiotics. Curr. Opin. Pharmacol. 2009, 9, 571-576. [CrossRef] [PubMed]

26. Nordström, R.; Malmsten, M. Delivery systems for antimicrobial peptides. Adv. Colloid Interface Sci. 2017, 242, 17-34. [CrossRef]

27. de Marco, R.; Cerisoli, L. Chemical Modifications Designed to Improve Peptide Stability: Incorporation of Non-Natural Amino Acids, Pseudo-Peptide Bonds, and Cyclization. Curr. Pharm. Des. 2010, 16, 3185-3203. [CrossRef]

28. Svendsen, J.S.M.; Grant, T.M.; Rennison, D.; Brimble, M.A.; Svenson, J. Very Short and Stable Lactoferricin-Derived Antimicrobial Peptides: Design Principles and Potential Uses. Acc. Chem. Res. 2019, 52, 749-759. [CrossRef]

29. Qvit, N.; Rubin, S.J.; Urban, T.J.; Mochly-Rosen, D.; Gross, E.R. Peptidomimetic therapeutics: Scientific approaches and opportunities. Drug Discov. Today 2017, 22, 454-462. [CrossRef]

30. Migoń, D.; Neubauer, D.; Kamysz, W. Hydrocarbon Stapled Antimicrobial Peptides. Protein J. 2018, 37, 2 -12. [CrossRef]

31. Spokoyny, A.M.; Zou, Y.; Ling, J.J.; Yu, H.; Lin, Y.-S.; Pentelute, B.L. A Perfluoroaryl-Cysteine SNAr Chemistry Approach to Unprotected Peptide Stapling. J. Am. Chem. Soc. 2013, 135, 5946-5949. [CrossRef] [PubMed]

32. Lautrette, G.; Touti, F.; Lee, H.G.; Dai, P.; Pentelute, B.L. Nitrogen Arylation for Macrocyclization of Unprotected Peptides. J. Am. Chem. Soc. 2016, 138, 8340-8343. [CrossRef] [PubMed] 
33. Jia, F.; Wang, J.; Peng, J.; Zhao, P.; Kong, Z.; Wang, K.; Yan, W.; Wang, R. D-amino acid substitution enhances the stability of antimicrobial peptide polybia-CP. Acta Biochim. Biophys. Sin. 2017, 49, 916-925. [CrossRef] [PubMed]

34. Zhao, Y.; Zhang, M.; Qiu, S.; Wang, J.; Peng, J.; Zhao, P.; Zhu, R.; Wang, H.; Li, Y.; Li, B.; et al. Antimicrobial activity and stability of the d-amino acid substituted derivatives of antimicrobial peptide polybia-MPI. $A M B$ Express 2016, 6, 122. [CrossRef]

35. Grimsey, E.; Collis, D.W.; Mikut, R.; Hilpert, K. The effect of lipidation and glycosylation on short cationic antimicrobial peptides. Biochim. Biophys. Acta Biomembr. 2020, 1862, 183195. [CrossRef]

36. Jerala, R. Synthetic lipopeptides: A novel class of anti-infectives. Expert Opin. Investig. Drugs 2007, 16, 1159-1169. [CrossRef]

37. Lombardi, L.; Shi, Y.; Falanga, A.; Galdiero, E.; De Alteriis, E.; Franci, G.; Chourpa, I.; Azevedo, H.S.; Galdiero, S. Enhancing the Potency of Antimicrobial Peptides through Molecular Engineering and Self-Assembly. Biomacromolecules 2019, 20, 1362-1374. [CrossRef]

38. Kamysz, E.; Sikorska, E.; Jaśkiewicz, M.; Bauer, M.; Neubauer, D.; Bauer, S.B.M.; Barańska-Rybak, W.; Kamysz, W. Lipidated Analogs of the LL-37-Derived Peptide Fragment KR12—Structural Analysis, Surface-Active Properties and Antimicrobial Activity. Int. J. Mol. Sci. 2020, 21, 887. [CrossRef]

39. Malina, A.; Shai, Y. Conjugation of fatty acids with different lengths modulates the antibacterial and antifungal activity of a cationic biologically inactive peptide. Biochem. J. 2005, 390, 695-702. [CrossRef]

40. Laverty, G.; McCloskey, A.P.; Gorman, S.P.; Gilmore, B.F. Anti-biofilm activity of ultrashort cinnamic acid peptide derivatives against medical device-related pathogens. J. Pept. Sci. 2015, 21, 770-778. [CrossRef]

41. Makovitzki, A.; Baram, J.; Shai, Y. Antimicrobial Lipopolypeptides Composed of Palmitoyl Di- and Tricationic Peptides: In Vitro and in Vivo Activities, Self-Assembly to Nanostructures, and a Plausible Mode of Action. Biochemistry 2008, 47, 10630-10636. [CrossRef] [PubMed]

42. Chu-Kung, A.F.; Nguyen, R.; Bozzelli, K.N.; Tirrell, M. Chain length dependence of antimicrobial peptide-fatty acid conjugate activity. J. Colloid Interface Sci. 2010, 345, 160-167. [CrossRef] [PubMed]

43. Majerle, A.; Kidrič, J.; Jerala, R. Enhancement of antibacterial and lipopolysaccharide binding activities of a human lactoferrin peptide fragment by the addition of acyl chain. J. Antimicrob. Chemother. 2003, 51, 1159-1165. [CrossRef] [PubMed]

44. Bisht, G.S.; Rawat, D.S.; Kumar, A.; Kumar, R.; Pasha, S. Antimicrobial activity of rationally designed amino terminal modified peptides. Bioorganic Med. Chem. Lett. 2007, 17, 4343-4346. [CrossRef]

45. Laverty, G.; McLaughlin, M.; Shaw, C.; Gorman, S.P.; Gilmore, B.F. Antimicrobial Activity of Short, Synthetic Cationic Lipopeptides. Chem. Biol. Drug Des. 2010, 75, 563-569. [CrossRef]

46. Albada, H.B.; Prochnow, P.; Bobersky, S.; Langklotz, S.; Schriek, P.; Bandow, J.E.; Metzler-Nolte, N. Tuning the Activity of a Short Arg-Trp Antimicrobial Peptide by Lipidation of a C- or N-Terminal Lysine Side-Chain. ACS Med. Chem. Lett. 2012, 3, 980-984. [CrossRef]

47. Porat, Y.; Marynka, K.; Tam, A.; Steinberg, D.; Mor, A. Acyl-Substituted Dermaseptin S4 Derivatives with Improved Bactericidal Properties, Including on Oral Microflora. Antimicrob. Agents Chemother. 2006, 50, 4153-4160. [CrossRef]

48. Radzishevsky, I.S.; Rotem, S.; Zaknoon, F.; Gaidukov, L.; Dagan, A.; Mor, A. Effects of Acyl versus Aminoacyl Conjugation on the Properties of Antimicrobial Peptides. Antimicrob. Agents Chemother. 2005, 49, 2412-2420. [CrossRef]

49. Nasompag, S.; Dechsiri, P.; Hongsing, N.; Phonimdaeng, P.; Daduang, S.; Klaynongsruang, S.; Camesano, T.A.; Patramanon, R. Effect of acyl chain length on therapeutic activity and mode of action of the CX-KYR-NH2 antimicrobial lipopeptide. Biochim. Biophys. Acta Biomembr. 2015, 1848, 2351-2364. [CrossRef]

50. Dong, W.; Liu, Z.; Sun, L.; Wang, C.; Guan, Y.; Mao, X.; Shang, D. Antimicrobial activity and self-assembly behavior of antimicrobial peptide chensinin-1b with lipophilic alkyl tails. Eur. J. Med. Chem. 2018, 150, 546-558. [CrossRef]

51. Chu-Kung, A.F.; Bozzelli, K.N.; Lockwood, N.A.; Haseman, J.R.; Mayo, K.H.; Tirrell, M.V. Promotion of Peptide Antimicrobial Activity by Fatty Acid Conjugation. Bioconj. Chem. 2004, 15, 530-535. [CrossRef] [PubMed]

52. Makovitzki, A.; Avrahami, D.; Shai, Y. Ultrashort antibacterial and antifungal lipopeptides. Proc. Natl. Acad. Sci. USA 2006, 103, 15997-16002. [CrossRef] [PubMed] 
53. Meir, O.; Zaknoon, F.; Cogan, U.; Mor, A. A broad-spectrum bactericidal lipopeptide with anti-biofilm properties. Sci. Rep. 2017, 7, 2198. [CrossRef] [PubMed]

54. Wakabayashi, H.; Matsumoto, H.; Hashimoto, K.; Teraguchi, S.; Takase, M.; Hayasawa, H. N-Acylated and d Enantiomer Derivatives of a Nonamer Core Peptide of Lactoferricin B Showing Improved Antimicrobial Activity. Antimicrob. Agents Chemother. 1999, 43, 1267-1269. [CrossRef]

55. Greber, K.E.; Dawgul, M.; Kamysz, W.; Sawicki, W.; Łukasiak, J. Biological and surface-active properties of double-chain cationic amino acid-based surfactants. Amino Acids 2014, 46, 1893-1898. [CrossRef] [PubMed]

56. Stachurski, O.; Neubauer, D.; Małuch, I.; Wyrzykowski, D.; Bauer, M.; Bartoszewska, S.; Kamysz, W.; Sikorska, E. Effect of self-assembly on antimicrobial activity of double-chain short cationic lipopeptides. Bioorg. Med. Chem. 2019, 27, 115129. [CrossRef]

57. Avrahami, D.; Shai, Y. Bestowing Antifungal and Antibacterial Activities by Lipophilic Acid Conjugation to D,L-Amino Acid-Containing Antimicrobial Peptides: A Plausible Mode of Action. Biochemistry 2003, 42, 14946-14956. [CrossRef]

58. Sikorska, E.; Stachurski, O.; Neubauer, D.; Małuch, I.; Wyrzykowski, D.; Bauer, M.; Brzozowski, K.; Kamysz, W. Short arginine-rich lipopeptides: From self-assembly to antimicrobial activity. Biochim. Biophys. Acta Biomembr. 2018, 1860, 2242-2251. [CrossRef]

59. Cochrane, S.A.; Lohans, C.T.; Brandelli, J.R.; Mulvey, G.; Armstrong, G.D.; Vederas, J.C. Synthesis and Structure-Activity Relationship Studies of N-Terminal Analogues of the Antimicrobial Peptide Tridecaptin A1. J. Med. Chem. 2014, 57, 1127-1131. [CrossRef]

60. Shoji, J.; Hinoo, H.; Sakazaki, R.; Kato, T.; Wakisaka, Y.; Mayama, M.; Matsuura, S.; Miwa, H. Isolation of tridecaptins A, B and C. Studies on antibiotics from the genus Bacillus. XXIII. J. Antibiot. 1978, 31, 646-651. [CrossRef]

61. Koh, J.-J.; Lin, H.; Caroline, V.; Chew, Y.S.; Pang, L.M.; Aung, T.T.; Li, J.; Lakshminarayanan, R.; Tan, D.T.H.; Verma, C.S.; et al. N-Lipidated Peptide Dimers: Effective Antibacterial Agents against Gram-Negative Pathogens through Lipopolysaccharide Permeabilization. J. Med. Chem. 2015, 58, 6533-6548. [CrossRef] [PubMed]

62. Siano, A.; Húmpola, M.V.; Rey, M.C.; Simonetta, A.; Tonarelli, G.G. Interaction of Acylated and Substituted Antimicrobial Peptide Analogs with Phospholipid-Polydiacetylene Vesicles. Correlation with their Biological Properties. Chem. Biol. Drug Des. 2011, 78, 85-93. [CrossRef] [PubMed]

63. Varnava, K.G.; Mohid, S.A.; Calligari, P.; Stella, L.; Reynisson, J.; Bhunia, A.; Sarojini, V. Design, Synthesis, Antibacterial Potential, and Structural Characterization of N-Acylated Derivatives of the Human Autophagy 16 Polypeptide. Bioconjug. Chem. 2019, 30, 1998-2010. [CrossRef] [PubMed]

64. Humpola, M.V.; Rey, M.C.; Simonetta, A.C.; Tonarelli, G.G.; Carballeira, N.M. Biological and structural effects of the conjugation of an antimicrobial decapeptide with saturated, unsaturated, methoxylated and branched fatty acids. J. Pept. Sci. 2017, 23, 45-55. [CrossRef]

65. Lee, J.; Kim, S.; Sim, J.-Y.; Lee, D.; Kim, H.H.; Hwang, J.S.; Lee, D.; Park, Z.-Y.; Kim, J.I. A potent antibacterial activity of new short d-enantiomeric lipopeptide against multi drug resistant bacteria. Biochim. Biophys. Acta Biomembr. 2019, 1861, 34-42. [CrossRef]

66. Rosenfeld, Y.; Lev, N.; Shai, Y. Effect of the Hydrophobicity to Net Positive Charge Ratio on Antibacterial and Anti-Endotoxin Activities of Structurally Similar Antimicrobial Peptides. Biochemistry 2010, 49, 853-861. [CrossRef]

67. Zhong, C.; Liu, T.; Gou, S.; He, Y.; Zhu, N.; Zhu, Y.; Wang, L.; Liu, H.; Zhang, Y.; Yao, J.; et al. Design and synthesis of new $\mathrm{N}$-terminal fatty acid modified-antimicrobial peptide analogues with potent in vitro biological activity. Eur. J. Med. Chem. 2019, 182, 111636. [CrossRef]

68. Fang, Y.; Zhong, W.; Wang, Y.; Xun, T.; Lin, D.; Liu, W.; Wang, J.; Lv, L.; Liu, S.; He, J. Tuning the antimicrobial pharmacophore to enable discovery of short lipopeptides with multiple modes of action. Eur. J. Med. Chem. 2014, 83, 36-44. [CrossRef]

69. Armas, F.; Pacor, S.; Ferrari, E.; Guida, F.; Pertinhez, T.A.; Romani, A.A.; Scocchi, M.; Benincasa, M. Design, antimicrobial activity and mechanism of action of Arg-rich ultra-short cationic lipopeptides. PLOS ONE 2019, 14, e0212447. [CrossRef]

70. Neubauer, D.; Jaśkiewicz, M.; Bauer, M.; Gołacki, K.; Kamysz, W. Ultrashort Cationic Lipopeptides-Effect of N-Terminal Amino Acid and Fatty Acid Type on Antimicrobial Activity and Hemolysis. Molecules 2020, 25, 257. [CrossRef] 
71. Paduszynska, M.A.; Maciejewska, M.; Neubauer, D.; Golacki, K.; Szymukowicz, M.; Bauer, M.; Kamysz, W. Influence of Short Cationic Lipopeptides with Fatty Acids of Different Chain Lengths on Bacterial Biofilms Formed on Polystyrene and Hydrogel Surfaces. Pharmaceutics 2019, 11, 506. [CrossRef] [PubMed]

72. Lohan, S.; Cameotra, S.S.; Bisht, G.S. Systematic Study of Non-Natural Short Cationic Lipopeptides as Novel Broad-Spectrum Antimicrobial Agents. Chem. Biol. Drug Des. 2013, 82, 557-566. [CrossRef]

73. Mohanram, H.; Bhattacharjya, S. $\beta$-Boomerang Antimicrobial and Antiendotoxic Peptides: Lipidation and Disulfide Bond Effects on Activity and Structure. Pharmaceutics 2014, 7, 482-501. [CrossRef] [PubMed]

74. Mak, P.; Pohl, J.; Dubin, A.; Reed, M.S.; E Bowers, S.; Fallon, M.T.; Shafer, W.M. The increased bactericidal activity of a fatty acid-modified synthetic antimicrobial peptide of human cathepsin $\mathrm{G}$ correlates with its enhanced capacity to interact with model membranes. Int. J. Antimicrob. Agents 2003, 21, 13-19. [CrossRef]

75. Cheng, J.T.; Hale, J.D.; Elliot, M.; Hancock, R.E.; Straus, S.K. Effect of Membrane Composition on Antimicrobial Peptides Aurein 2.2 and 2.3 From Australian Southern Bell Frogs. Biophys. J. 2009, 96, 552-565. [CrossRef] [PubMed]

76. Haney, E.F.; Brito-Sánchez, Y.; Trimble, M.J.; Mansour, S.C.; Cherkasov, A.; Hancock, R.E. Computer-aided Discovery of Peptides that Specifically Attack Bacterial Biofilms. Sci. Rep. 2018, 8, 1871. [CrossRef] [PubMed]

77. Cherkasov, A.; Hilpert, K.; Jenssen, H.; Fjell, C.D.; Waldbrook, M.; Mullaly, S.C.; Volkmer, R.; Hancock, R.E.W. Use of Artificial Intelligence in the Design of Small Peptide Antibiotics Effective against a Broad Spectrum of Highly Antibiotic-Resistant Superbugs. ACS Chem. Biol. 2009, 4, 65-74. [CrossRef] [PubMed]

78. Greber, K.E.; Ciura, K.; Belka, M.; Kawczak, P.; Nowakowska, J.; Bączek, T.; Sawicki, W. Characterization of antimicrobial and hemolytic properties of short synthetic cationic lipopeptides based on QSAR/QSTR approach. Amino Acids 2018, 50, 479-485. [CrossRef]

79. Kumar, P.; Pletzer, D.; Haney, E.F.; Rahanjam, N.; Cheng, J.T.J.; Yue, M.; Aljehani, W.; Hancock, R.E.W.; Kizhakkedathu, J.N.; Straus, S.K. Aurein-Derived Antimicrobial Peptides Formulated with Pegylated Phospholipid Micelles to Target Methicillin-Resistant Staphylococcus aureus Skin Infections. ACS Infect. Dis. 2018, 5, 443-453. [CrossRef]

80. Ting, D.S.J.; Beuerman, R.W.; Dua, H.S.; Lakshminarayanan, R.; Mohammed, I. Strategies in Translating the Therapeutic Potentials of Host Defense Peptides. Front. Immunol. 2020, 11, 983. [CrossRef]

81. Falciani, C.; Lozzi, L.; Pollini, S.; Luca, V.; Carnicelli, V.; Brunetti, J.; Lelli, B.; Bindi, S.; Scali, S.; di Giulio, A.; et al. Isomerization of an Antimicrobial Peptide Broadens Antimicrobial Spectrum to Gram-Positive Bacterial Pathogens. PLoS ONE 2012, 7, e46259. [CrossRef] [PubMed]

82. de Zoysa, G.H.; Cameron, A.J.; Hegde, V.V.; Raghothama, S.; Sarojini, V. Antimicrobial Peptides with Potential for Biofilm Eradication: Synthesis and Structure Activity Relationship Studies of Battacin Peptides. J. Med. Chem. 2015, 58, 625-639. [CrossRef] [PubMed]

83. Hasan, A.; Saxena, V.; Castelletto, V.; Zimbitas, G.; Seitsonen, J.; Ruokolainen, J.; Pandey, L.M.; Sefcik, J.; Hamley, I.W.; Lau, K.H.A. Chain-End Modifications and Sequence Arrangements of Antimicrobial Peptoids for Mediating Activity and Nano-Assembly. Front. Chem. 2020, 8, 416. [CrossRef] [PubMed]

84. Lau, K.H.A.; Castelletto, V.; Kendall, T.; Sefcik, J.; Hamley, I.W.; Reza, M.; Ruokolainen, J. Self-assembly of ultra-small micelles from amphiphilic lipopeptoids. Chem. Commun. 2017, 53, 2178-2181. [CrossRef]

85. Mangoni, M.L.; Papo, N.; Saugar, J.M.; Barra, D.; Shai, Y.; Simmaco, M.; Rivas, L. Effect of Naturall-tod-Amino Acid Conversion on the Organization, Membrane Binding, and Biological Function of the Antimicrobial Peptides Bombinins H. Biochemistry 2006, 45, 4266-4276. [CrossRef]

86. Saravanan, R.; Bhunia, A.; Bhattacharjya, S. Micelle-bound structures and dynamics of the hinge deleted analog of melittin and its diastereomer: Implications in cell selective lysis by d-amino acid containing antimicrobial peptides. Biochim. Biophys. Acta Biomembr. 2010, 1798, 128-139. [CrossRef]

87. Oren, Z.; Shai, Y. Selective lysis of bacteria but not mammalian cells by diastereomers of melittin: Structure-function study. Biochemistry 1997, 36, 1826-1835. [CrossRef]

88. Mourtada, R.; Herce, H.D.; Yin, D.J.; Moroco, J.A.; Wales, T.E.; Engen, J.R.; Walensky, L.D. Design of stapled antimicrobial peptides that are stable, nontoxic and kill antibiotic-resistant bacteria in mice. Nat. Biotechnol. 2019, 37, 1186-1197. [CrossRef]

89. Raheem, N.; Kumar, P.; Lee, E.; Cheng, J.T.; Hancock, R.E.; Straus, S.K. Insights into the mechanism of action of two analogues of aurein 2.2. Biochim. Biophys. Acta Biomembr. 2020, 1862, 183262. [CrossRef] 
90. Haney, E.F.; Nguyen, L.T.; Schibli, D.J.; Vogel, H.J. Design of a novel tryptophan-rich membrane-active antimicrobial peptide from the membrane-proximal region of the HIV glycoprotein, gp41. Beilstein J. Org. Chem. 2012, 8, 1172-1184. [CrossRef]

91. Bhattacharjya, S.; Straus, S.K. Design, Engineering and Discovery of Novel $\alpha$-Helical and $\beta$-Boomerang Antimicrobial Peptides against Drug Resistant Bacteria. Int. J. Mol. Sci. 2020, 21, 5773. [CrossRef] [PubMed]

92. Jiang, Z.; Vasil, A.I.; Gera, L.; Vasil, M.L.; Hodges, R.S. Rational Design of $\alpha$-Helical Antimicrobial Peptides to Target Gram-negative Pathogens, Acinetobacter baumannii and Pseudomonas aeruginosa: Utilization of Charge, 'Specificity Determinants,' Total Hydrophobicity, Hydrophobe Type and Location as Design Para. Chem. Biol. Drug Des. 2011, 77, 225-240. [CrossRef] [PubMed]

93. Torres, M.D.T.; Pedron, C.N.; Higashikuni, Y.; Kramer, R.M.; Cardoso, M.H.; Oshiro, K.G.N.; Franco, O.L.; Silva, P.I., Jr.; Silva, F.D.; Oliveira, V.X., Jr.; et al. Structure-function-guided exploration of the antimicrobial peptide polybia-CP identifies activity determinants and generates synthetic therapeutic candidates. Commun. Biol. 2018, 1, 221. [CrossRef] [PubMed]

94. Saravanan, R.; Li, X.; Lim, K.; Mohanram, H.; Peng, L.; Mishra, B.; Basu, A.; Lee, J.-M.; Bhattacharjya, S.; Leong, S.S. Design of short membrane selective antimicrobial peptides containing tryptophan and arginine residues for improved activity, salt-resistance, and biocompatibility. Biotechnol. Bioeng. 2013, 111, 37-49. [CrossRef] [PubMed]

95. Chan, D.I.; Prenner, E.J.; Vogel, H.J. Tryptophan- and arginine-rich antimicrobial peptides: Structures and mechanisms of action. Biochim. Biophys. Acta Biomembr. 2006, 1758, 1184-1202. [CrossRef] [PubMed]

96. Rao, S.S.; Mohan, K.V.; Atreya, C.D. A Peptide Derived from Phage Display Library Exhibits Antibacterial Activity against E. coli and Pseudomonas aeruginosa. PLoS ONE 2013, 8, e56081. [CrossRef]

97. Etayash, H.; Pletzer, D.; Kumar, P.; Straus, S.K.; Hancock, R.E.W. Cyclic Derivative of Host-Defense Peptide IDR-1018 Improves Proteolytic Stability, Suppresses Inflammation, and Enhances In Vivo Activity. J. Med. Chem. 2020, 63, 9228-9236. [CrossRef]

98. Schafmeister, C.E.; Po, J.; Verdine, G.L. An All-Hydrocarbon Cross-Linking System for Enhancing the Helicity and Metabolic Stability of Peptides. J. Am. Chem. Soc. 2000, 122, 5891-5892. [CrossRef]

99. Molchanova, N.; Hansen, A.P.P.R.; Franzyk, A.P.H. Advances in Development of Antimicrobial Peptidomimetics as Potential Drugs. Molecules 2017, 22, 1430. [CrossRef]

100. Ghosh, C.; Sarkar, P.; Issa, R.; Haldar, J. Alternatives to Conventional Antibiotics in the Era of Antimicrobial Resistance. Trends Microbiol. 2019, 27, 323-338. [CrossRef]

101. Mendez-Samperio, P. Peptidomimetics as a new generation of antimicrobial agents: Current progress. Infect. Drug Resist. 2014, 7, 229-237. [CrossRef] [PubMed]

102. Kowalski, R.P.; Romanowski, E.G.; Yates, K.A.; Mah, F.S. An Independent Evaluation of a Novel Peptide Mimetic, Brilacidin (PMX30063), for Ocular Anti-Infective. J. Ocul. Pharmacol. Ther. 2016, 32, $23-27$. [CrossRef] [PubMed]

103. Luther, A.; Urfer, M.; Zahn, M.; Müller, M.; Wang, S.-Y.; Mondal, M.; Vitale, A.; Hartmann, J.-B.; Sharpe, T.; Monte, F.L.; et al. Chimeric peptidomimetic antibiotics against Gram-negative bacteria. Nat. Cell Biol. 2019, 576, 452-458. [CrossRef] [PubMed]

104. Siriwardena, T.N.; Stach, M.; He, R.; Gan, B.-H.; Javor, S.; Heitz, M.; Ma, L.; Cai, X.; Chen, P.; Wei, D.; et al. Lipidated Peptide Dendrimers Killing Multidrug-Resistant Bacteria. J. Am. Chem. Soc. 2018, 140, 423-432. [CrossRef]

105. Stanton, T.B. A call for antibiotic alternatives research. Trends Microbiol. 2013, 21, 111-113. [CrossRef] [PubMed]

106. Hancock, R.E.; Sahl, H.-G. Antimicrobial and host-defense peptides as new anti-infective therapeutic strategies. Nat. Biotechnol. 2006, 24, 1551-1557. [CrossRef]

Publisher's Note: MDPI stays neutral with regard to jurisdictional claims in published maps and institutional affiliations. 